\title{
WATER CHEMISTRY, PHYTOPLANKTON DIVERSITY AND SEVERE EUTROPHICATION WITH DETECTION OF MICROCYSTIN CONTENTS IN THAI TROPICAL URBAN PONDS
}

\author{
PRASERTPHON, R. ${ }^{1}-$ JiTCHUM, ${ }^{2}{ }^{2}-$ CHAICHANA, R..$^{1,3^{*}}$ \\ ${ }^{I}$ Department of Environmental Technology and Management, Faculty of Environment, \\ Kasetsart University, Bangkok, Thailand \\ ${ }^{2}$ Department of Fishery Biology, Faculty of Fisheries, Kasetsart University, Bangkok, Thailand \\ ${ }^{3}$ Research Group: Natural Environment in Forest and Freshwater Ecosystems, Faculty of \\ Environment, Kasetsart University, Bangkok, Thailand \\ ${ }^{*}$ Corresponding author \\ e-mail: fscircc@ku.ac.th; phone:+662-579-2945; fax:+662-579-2946
}

(Received 20 ${ }^{\text {th }}$ Mar 2020; accepted $2^{\text {nd }}$ Jul 2020)

\begin{abstract}
This study investigated eutrophication and the microcystin contents in urban ponds prone to the influx of excessive nutrients. We sampled urban ponds in five provinces (Khon Kaen, Chanthaburi, Chiang Mai, Bangkok and Pathum Thani) in different regions of Thailand. Water and phytoplankton samples were determined between the end of the cold and hot seasons in 2018-2019. The results revealed that all the urban ponds were in a hypereutrophic condition as indicated by the Florida trophic state index. Nutrients were exceptionally high in both the cold and hot seasons. The Cyanophyceae were common and abundant in most urban ponds and increased from the cold season into the hot season. Cluster analysis and multidimensional scaling indicated unique phytoplankton composition among the urban ponds. Dissimilarities in the phytoplankton among the urban ponds increased from the cold season to the hot season. Microcystin analysis showed that an urban pond in Pathum Thani province contained the highest mean microcystin content during cold $(3.62 \pm 0.43 \mu \mathrm{g} / \mathrm{L})$ and hot $(3.10 \pm 0.97 \mu \mathrm{g} / \mathrm{L})$ seasons. In conclusion, there is an urgent need for the restoration of urban ponds in Thailand. In particular, controlling external and internal nutrient sources should be a main focus together with regular monitoring of eutrophication.
\end{abstract}

Keywords: chlorophyll a, cyanotoxin, microcystis, nitrogen, phosphorus, trophic state index

\section{Introduction}

Urban ponds in urbanized landscapes are important and play several roles (Oertli and Parris, 2019). In ecosystems, ponds serve as a network of habitat patches (Hassall, 2014) and thus are inhabited by several plant and animal species. The ponds provide food sources and a breeding ground for species like invertebrates (snails and insects) and vertebrates (amphibians and fish) (Hamer et al., 2012), while maintaining ecosystem integrity and biodiversity in the city (Hassall, 2014). Ponds also provide ecosystem services to the people living in cities (Hill et al., 2017). The main services are cultural services including recreation, education and inspiration (Ghermandi and Fichtman, 2015). Urban ponds are an attraction for visitors in public parks where ponds are located. In addition, urban ponds provide regulating services such as water purification, flood control and water storage (Tixier et al., 2011; Sun et al., 2019). In particular, excess water during heavy rain can be stored in urban ponds to avoid flooding in the city areas. Although urban ponds are essential to wildlife and people, they are exposed to anthropogenic activities that have resulted in the deterioration of water quality and quantity of the urban ponds (Tixier et al., 2011). 
Urban ponds are prone to eutrophication due to the addition of excessive nutrients (Waajen et al., 2014). Nutrient inputs of urban ponds come from several sources such as fertilizers applied on lawns, land runoff, artificial fish and bird feeding (Chaichana et al., 2011) and treated and untreated wastewater from surrounding areas (Oshima et al., 2008). Previous studies showed that urban ponds contained large quantities of nutrients and that eutrophication was present. In Belgium, for example, 42 urban ponds had high amounts of total phosphorus $(0.1 \mathrm{mg} / \mathrm{L})$ and cyanobacterial blooms were detected (such as Anabaena, Aphanizomenon, Microcystis and Planktothrix) (Peretyatko et al., 2010). In the Netherlands, eutrophication of urban ponds was induced by wastewater from communities and rainwater drainage (Total phosphorus (TP) 0.16-0.44 mg/L), with blooms of phytoplankton occurring, which were dominated by Microcystis, Anabaena and Planktothrix (Waajen et al., 2014). Eutrophication as a form of water pollution in urban ponds exerts ecological impacts. Eutrophication thus reduces potential of ponds and their usefulness since the ponds themselves remain important, but they are unable to fulfill their potential.

A particular concern is eutrophication accompanied by harmful algal blooms. Several phytoplankton species in the Division Cyanophyta produce toxic substances which can be divided into several categories such as hepatotoxin, cytotoxin, neurotoxin and dermatotoxin (Sivonen, 2009). The most common toxic substance is microcystin. Microcystin is a secondary metabolite produced by Microcystis, Anabaena, Planktothrix (Oscillatoria), Nostoc, Hapalosiphon and Anabaenopsis (Bartram and Chorus, 1999). These toxic compounds can pose a threat to wildlife and water users (Waajen et al., 2016; Tilahun et al., 2019). In Lake Zumpango, Mexico, for example, microcystin can accumulate through trophic levels and was found in the liver of Oreochromis niloticus (Zamora-Barrios et al., 2019).

In Thailand, eutrophication is one of the most important water pollution problems. Thailand is a tropical country where eutrophication is widespread and common due to a combination of nutrients, high temperature and abundance of sunlight throughout the year. Previous studies have revealed blooms of Microcystis, Oscillatoria, Planktolyngbya, Planktotrix and Pseudanabaena in recreational reservoirs in Khon Kaen province in north-eastern Thailand (Somdee et al., 2013). In reservoirs in northern Thailand, blooms of Microcystis aeruginosa resulted in microcystin being found in Nile Tilapia (Oreochromis niloticus) (Aroonvilairat et al., 2004; Seekhao et al., 2007; Whangchai et al., 2013). Studies of eutrophication in Thailand have so far focused on reservoirs (for drinking purposes). Relatively little attention has been given to urban ponds, which could also be at risk of eutrophication and contamination by microcystin. Therefore, this research focused on documenting eutrophication in urban ponds in Thailand. The objectives were to investigate the water quality, trophic states of urban ponds in four regions between the cold and hot seasons and to determine phytoplankton diversity and composition. The microcystin contents were assessed to provide data that could be used to help monitor and manage eutrophication in urban ponds.

\section{Materials and Methods}

\section{Study sites}

Five urban ponds located in cities of five provinces in different parts of Thailand were selected for this study as eutrophication has occurred in these urban ponds (Fig. 1). The names of the ponds are: 1) Bueng Nong Khot in Khon Kaen province in the northeast, 2) 
pond in Somdej Phrachao Taksin Maharat Public Park in Chanthaburi province in the east, 3) Nong Ho in Chiang Mai province in the north, 4) the Bueng beside the Railway Hospital in Bangkok in central Thailand and 5) Bueng Yai in Pathum Thani province in central Thailand ('Bueng' and 'Nong' in Thai mean pond). Details of each urban pond are given in Table 1.

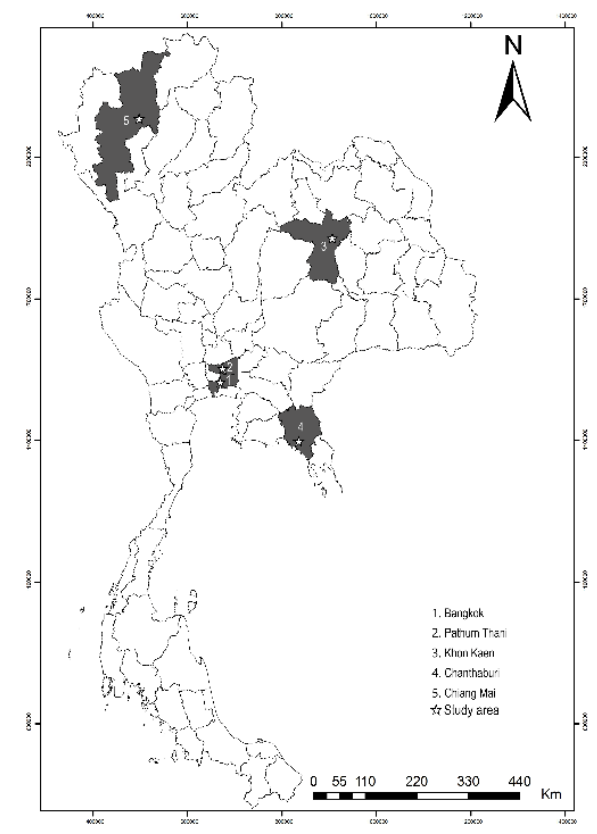

Figure 1. Locations of five urban ponds in five provinces of Thailand

Table 1. Locations and details of selected urban ponds

\begin{tabular}{|c|c|c|c|c|c|}
\hline Detail & Khon Kaen & Chanthaburi & Chiang Mai & Bangkok & Pathum Thani \\
\hline Location & Northeast & East & North & Central & Central \\
\hline $\begin{array}{l}\text { Coordinate } \\
\text { (North) }\end{array}$ & $16^{\circ} 25^{\prime} 55^{\prime \prime} \mathrm{N}$ & $12^{\circ} 36^{\prime} 18^{\prime \prime} \mathrm{N}$ & $18^{\circ} 49^{\prime} 15^{\prime \prime} \mathrm{N}$ & $13^{\circ} 45^{\prime} 05^{\prime \prime} \mathrm{N}$ & $13^{\circ} 59^{\prime} 42^{\prime \prime} \mathrm{N}$ \\
\hline $\begin{array}{l}\text { Coordinate } \\
\text { (East) }\end{array}$ & $102^{\circ} 47^{\prime} 58^{\prime \prime} \mathrm{E}$ & $102^{\circ} 06^{\prime} 21 " \mathrm{E}$ & $98^{\circ} 58^{\prime} 31^{\prime \prime E}$ & $100^{\circ} 33^{\prime} 11^{\prime \prime E}$ & $100^{\circ} 36^{\prime} 31^{\prime \prime} \mathrm{E}$ \\
\hline Area $\left(\mathrm{m}^{2}\right)$ & $1,047,690$ & 181,950 & 84,102 & 9,666 & 82,162 \\
\hline Depth $(\mathrm{m})$ & 6 & 6 & 3 & 3 & 8 \\
\hline Purposes & $\begin{array}{l}\text { Water storage for } \\
\text { flood control, } \\
\text { recreation, } \\
\text { fishing and } \\
\text { sports }\end{array}$ & $\begin{array}{l}\text { Public park, fish } \\
\text { feeding. This pond } \\
\text { receives } \\
\text { discharged water } \\
\text { from wastewater } \\
\text { treatment plant. }\end{array}$ & $\begin{array}{l}\text { Recreation, } \\
\text { surrounded by } \\
\text { local restaurants }\end{array}$ & $\begin{array}{c}\text { Water storage, } \\
\text { surrounded by } \\
\text { houses and } \\
\text { restaurants }\end{array}$ & $\begin{array}{l}\text { Water storage for } \\
\text { flood control }\end{array}$ \\
\hline
\end{tabular}

\section{Sampling collection and analysist}

\section{Sampling of water and plankton}

In each pond, water samples were collected from three sampling points across the ponds. Water samples were taken twice in the cold season (Dec-Jan 2019) and in the hot season (MarApr 2019). We measured water quality on site based on: dissolved oxygen (DO, mg/L), $\mathrm{pH}$, 
temperature $\left({ }^{\circ} \mathrm{C}\right)$, conductivity $(\mu \mathrm{s} / \mathrm{cm})$ and total dissolved solid (TDS, $\left.\mathrm{mg} / \mathrm{L}\right)$ using a multiparameter analyser (Consort 9116). Water transparency and depth were also studied using a Secchi disk. In addition, two $\mathrm{L}$ of water samples were collected and kept in plastic bottles and then put in a container at four ${ }^{\circ} \mathrm{C}$ for further analysis in the laboratory. We analysed ammoniumN using the phenol-hypochlorite method (Strickland and Parsons, 1972), soluble reactive phosphorus (SRP) using the ascorbic acid method, total nitrogen (TN) using the Kjeldahl method, total phosphorus (TP) using the vanadomolybdate method, total suspended solid (TSS) using filtration and chlorophyll a using the acetone extraction method. All samples were analysed in triplicate at the Department of Environmental Technology and Management, Faculty of Environment, Kasetsart University and Central Laboratory, Bangkok, Thailand.

Phytoplankton was collected using a $20 \mu \mathrm{m}$ plankton net. Sampling points for plankton were at the same locations as the water sampling points. A sample of ten $\mathrm{L}$ of water was passed through each plankton net. Samples were then preserved in 70\% ethanol. Plankton samples were investigated by counting and classifying up to the species level using a Sedgewick-Rafter counting chamber under compound light microscope.

Toxic analysis

Microcystin was analysed using a Microcystin-Adda ELISA kit (Abraxis, USA). Samples of water were collected and then filtered using a glass microfiber filter, grade GF/C (diameter $47 \mathrm{~mm}$ ) Whatman. Toxic analysis was done in the laboratory by measuring the absorbance at $450 \mathrm{~nm}$ wavelength using a microplate spectrophotometer (Powerwave 340, Biotek, USA).

\section{Data analysis}

Data presented as mean \pm standard deviation. We used the Florida trophic state index (TSI) to classify the urban ponds based on chlorophyll levels and the nitrogen and phosphorus concentrations (Huber et al., 1982). The trophic state index equations are:

$$
\begin{gathered}
C H L A_{T S I}=16.8+[14.4 \times L N(C H L A)] \\
T N_{T S I}=56+[19.8+L N(T N)] \\
T N 2_{T S I}=10 \times[5.96+2.15 \times L N(T N+0.0001)] \\
T P_{T S I}=[18.6 \times L N(T P \times 1000)]-18.4 \\
T P 2_{T S I}=10 \times[2.36 \times L N(T P \times 1000)]-2.38
\end{gathered}
$$

Limiting nutrient considerations for calculating $N U T R_{T S I}$

- If $T N / T P>30$, then $N U T R_{T S I}=T P 2_{T S I}$.

- If $T N / T P<10$, then $N U T R_{T S I}=T N 2_{T S I}$.

- If $10<T N / T P<30$, then $N U T R_{T S I}=\left(T P_{T S I}+T N_{T S I}\right) / 2$.

$$
T S I=\left(C H L A_{T S I}+N U T R I_{T S I}\right) / 2
$$

In equations, CHLA is chlorophyll a $(\mu \mathrm{g} / \mathrm{L}), \mathrm{TN}$ is total nitrogen $(\mathrm{mg} / \mathrm{L}), \mathrm{TP}$ is total phosphorus $(\mathrm{mg} / \mathrm{L}), \mathrm{LN}$ is natural $\log$ and NUTR is nutrient. The final TSI can then be used to classify trophic state. TSI less than 60 indicates that a lake is oligotrophic to mid-eutrophic. TSI 
between 60 and 69 indicates that a lake is mid-eutrophic to eutrophic. TSI higher than 70 indicate that a lake is hypereutrophic.

Limiting nutrient was calculated by TN/TP ratio (Lakewatch, 2000). When the TN/TP ratio is less than 10, a lake is nitrogen-limited. When the TN/TP ratio is between 10 and 17, nitrogen or phosphorus could be limiting and when the TN/TP ratio is greater than 17, a lake is phosphorus-limited.

Differences in water quality parameters and phytoplankton abundances between seasons was determined using a Student t-test by using SPSS 23. Correlation coefficient between microcystin content and cyanobacteria was also tested. The Primer seven software package was used to analyze nonmetric multi-dimensional scaling (MDS). MDS displays the spatial distribution of variables (phytoplankton) among provinces, thus indicating similarities or dissimilarities among variables. Cluster analysis was also performed to group similar variables of phytoplankton. Data were log-transformed and standardized.

\section{Results}

\section{Water quality}

The water quality analysis revealed that all urban ponds were in hypereutrophic conditions in both the cold and hot seasons as indicated by the Florida trophic state index (Table 2). Water quality varied among ponds and between seasons (Table 3). Nutrient concentrations were exceptionally high. In the cold season, TN concentrations were in the range $2.92-13.13 \mathrm{mg} / \mathrm{L}$. The highest $\mathrm{TN}$ value was in Khon Kaen province $(13.13 \mathrm{mg} / \mathrm{L})$. TP values were in the range $0.10-1.43 \mathrm{mg} / \mathrm{L}$. The highest TP value was detected in Bangkok $(1.43 \mathrm{mg} / \mathrm{L})$. Chlorophyll a values were in the range 45.68$4,022.09 \mu \mathrm{g} / \mathrm{L}$. The highest value was in Chiang Mai province $(4,022.09 \mu \mathrm{g} / \mathrm{L})$.

Table 2. Florida trophic state index of sampled urban ponds

\begin{tabular}{ccccccccc}
\hline \multirow{2}{*}{ Province } & Season & $\begin{array}{c}\text { Trophic } \\
\text { State } \\
\text { Index } \\
\text { (Chl a) }\end{array}$ & $\begin{array}{c}\text { Trophic } \\
\text { State } \\
\text { Index } \\
\text { (TP) }\end{array}$ & $\begin{array}{c}\text { Trophic } \\
\text { State } \\
\text { Index 2 } \\
\text { (TP) }\end{array}$ & $\begin{array}{c}\text { Trophic } \\
\text { State } \\
\text { Index } \\
\text { (TN) }\end{array}$ & $\begin{array}{c}\text { Trophic } \\
\text { State } \\
\text { Index 2 } \\
\text { (TN) }\end{array}$ & $\begin{array}{c}\text { Trophic } \\
\text { State } \\
\text { Index }\end{array}$ & State \\
\hline \multirow{2}{*}{ Khon Kaen } & C & 83.65 & - & 76.85 & - & - & 80.25 & Hypereutrophic \\
Chanthaburi & H & 71.71 & - & - & - & - & 87.95 & Hypereutrophic \\
Chiang Mai & H & 71.76 & - & 95.52 & - & - & 83.64 & Hypereutrophic \\
& C & 98.25 & - & - & - & 106.23 & 102.24 & Hypereutrophic \\
Bangkok & H & 90.34 & - & - & - & 101.28 & 95.81 & Hypereutrophic \\
\multirow{2}{*}{ Pathum Thani } & C & 87.33 & - & - & - & 91.36 & 89.34 & Hypereutrophic \\
& H & 108.25 & - & - & - & 91.36 & 99.80 & Hypereutrophic \\
& C & 114.90 & - & - & - & 98.80 & 106.85 & Hypereutrophic \\
& H & 77.41 & - & - & - & 106.24 & 91.81 & Hypereutrophic \\
\hline
\end{tabular}

Remark: $\mathrm{C}=$ cold season, $\mathrm{H}=$ hot season

In the hot season, the TN concentrations were in the range $1.46-8.75 \mathrm{mg} / \mathrm{L}$, with the highest value $(8.75 \mathrm{mg} / \mathrm{L})$ in Khon Kaen province. The TP values were in the range 0.25 $34.80 \mathrm{mg} / \mathrm{L}$, with the highest value in Chiang Mai $(38.36 \mathrm{mg} / \mathrm{L})$. The chlorophyll a values were in the range 46.00-576.61 $\mu \mathrm{g} / \mathrm{L}$ and the highest value was in Bangkok $(736.80 \mu \mathrm{g} / \mathrm{L})$. 
Table 3. Water quality of urban ponds in Thailand in cold $(C)$ and hot $(H)$ seasons

\begin{tabular}{|c|c|c|c|c|c|c|c|c|c|c|}
\hline \multirow{2}{*}{ Parameter } & \multicolumn{2}{|c|}{ Khon Kaen } & \multicolumn{2}{|c|}{ Chanthaburi } & \multicolumn{2}{|c|}{ Chiang Mai } & \multicolumn{2}{|c|}{ Bangkok } & \multicolumn{2}{|c|}{ Pathum Thani } \\
\hline & $\mathbf{C}$ & $\mathbf{H}$ & $\mathbf{C}$ & $\mathbf{H}$ & $\mathbf{C}$ & $\mathbf{H}$ & $\mathbf{C}$ & $\mathbf{H}$ & $\mathbf{C}$ & $\mathbf{H}$ \\
\hline DO (mg/L) & $3.9 \pm 0.2$ & $3.8 \pm 1.4$ & $5.5 \pm 1.3$ & $4.3 \pm 1.9$ & $3.5 \pm 1.7$ & $6.0 \pm 3.2$ & $10.0 \pm 0.6^{*}$ & $16.0 \pm 0.5^{*}$ & $11.8 \pm 0.3^{*}$ & $7.6 \pm 1.0^{*}$ \\
\hline $\mathrm{T}_{\text {water }}\left({ }^{\circ} \mathrm{C}\right)$ & $28 \pm 2$ & $34 \pm 1$ & $30 \pm 2$ & $33 \pm 1$ & $27 \pm 2^{*}$ & $35 \pm 0^{*}$ & $29 \pm 0^{*}$ & $35 \pm 0^{*}$ & $31 \pm 1^{*}$ & $34 \pm 1^{*}$ \\
\hline $\mathrm{pH}$ & $8.1 \pm 0.1$ & $8.6 \pm 0.6$ & $7.4 \pm 0.2^{*}$ & $6.7 \pm 0.1^{*}$ & $7.2 \pm 0.1^{*}$ & $9.9 \pm 0.1^{*}$ & $8.3 \pm 0.1^{*}$ & $8.7 \pm 0.1^{*}$ & $9.4 \pm 0.3^{*}$ & $8.8 \pm 0.1^{*}$ \\
\hline $\mathrm{TSS}(\mathrm{mg} / \mathrm{L})$ & $28.9 \pm 8.4$ & $32.0 \pm 18.8$ & $34.4 \pm 9.3^{*}$ & $51.1 \pm 4.7^{*}$ & $59.3 \pm 33.3$ & $81.3 \pm 4.1$ & $98.7 \pm 124.3$ & $70.4 \pm 8.3$ & $181.8 \pm 123.0^{*}$ & $36.4 \pm 20.3^{*}$ \\
\hline Turbidity (NTU) & $23 \pm 7$ & $17 \pm 3$ & $38 \pm 6^{*}$ & $44 \pm 3^{*}$ & $101 \pm 65^{*}$ & $111 \pm 45^{*}$ & $32 \pm 6^{*}$ & $40 \pm 7^{*}$ & $309 \pm 265$ & $16 \pm 5$ \\
\hline Trans. (cm) & $43.33 \pm 7.64$ & $28.33 \pm 7.64$ & $26.67 \pm 5.77$ & $20.00 \pm 0.00$ & $12.67 \pm 21.94$ & $15.00 \pm 4.36$ & $30.00 \pm 5.00$ & $24.00 \pm 22.54$ & $11.67 \pm 16.07$ & $29.67 \pm 13.05$ \\
\hline TDS (mg/L) & $386 \pm 3$ & $398 \pm 10$ & $169 \pm 3$ & $475 \pm 27$ & $143 \pm 12$ & $93 \pm 1$ & $456 \pm 3$ & $389 \pm 1$ & $264 \pm 3$ & $227 \pm 2$ \\
\hline Conductivity $(\mu \mathrm{s} / \mathrm{cm})$ & $621 \pm 10^{*}$ & $714 \pm 20^{*}$ & $282 \pm 7$ & $837 \pm 41$ & $243 \pm 3$ & $170 \pm 2$ & $762 \pm 7$ & $715 \pm 5$ & $450 \pm 9$ & $411 \pm 8$ \\
\hline Salinity (mg/L) & $0.3 \pm 0.0$ & $0.4 \pm 0.1$ & $0.10 \pm 0.00$ & $0.4 \pm 0.0$ & $0.1 \pm 0.0$ & $0.1 \pm 0.0$ & $0.3 \pm 0.0$ & $0.3 \pm 0.00$ & $0.2 \pm 0.00$ & $0.2 \pm 0.00$ \\
\hline Chl a $(\mu \mathrm{g} / \mathrm{L})$ & $119.70 \pm 77.83$ & $46.00 \pm 9.63$ & $45.68 \pm 5.803$ & $301.20 \pm 120.66$ & $4022.09 \pm 6642.16$ & $87.22 \pm 116.77$ & $7134.08 \pm 6.07^{*}$ & $576.51 \pm 76.95^{*} 1$ & $1288.25 \pm 1268.69$ & $972.59 \pm 33.82$ \\
\hline $\mathrm{NH}_{4}(\mu \mathrm{g} / \mathrm{L})$ & $251.84 \pm 97.22$ & $90.81 \pm 42.51$ & ND & $2.86 \pm 19.49$ & $152.85 \pm 243.18$ & $0.45 \pm 5.76$ & $12.22 \pm 14.10^{*} 5$ & $62.45 \pm 151.12^{*}$ & $0.67 \pm 1.25$ & $26.16 \pm 25.59$ \\
\hline $\operatorname{SRP}(\mu \mathrm{g} / \mathrm{L})$ & $13.69 \pm 4.24$ & $7.96 \pm 5.63$ & $9.25 \pm 1.60$ & $19.19 \pm 5.58$ & $10.98 \pm 7.74$ & $14.60 \pm 3.05$ & $773.33 \pm 4.70^{*}$ & $681.89 \pm 6.35^{*}$ & $329.33 \pm 87.77^{*}$ & $18.11 \pm 4.21^{*}$ \\
\hline $\mathrm{TN}(\mathrm{mg} / \mathrm{L})$ & $13.13 \pm 4.38^{*}$ & $8.75 \pm 4.38^{*}$ & $5.83 \pm 5.05$ & $2.92 \pm 5.05$ & $4.38 \pm 3.09$ & $8.75 \pm 7.57$ & $2.92 \pm 2.53$ & $1.46 \pm 2.53$ & $4.38 \pm 3.09$ & $2.92 \pm 5.05$ \\
\hline $\mathrm{TP}(\mathrm{mg} / \mathrm{L})$ & $0.10 \pm 0.09$ & $0.25 \pm 0.41$ & $0.18 \pm 0.10^{*}$ & $26.69 \pm 2.36^{*}$ & $1.19 \pm 0.06^{*}$ & $34.80 \pm 4.42^{*}$ & $1.43 \pm 0.03^{*}$ & $26.69 \pm 2.36^{*}$ & $1.33 \pm 0.67^{*}$ & $17.35 \pm 5.11^{*}$ \\
\hline
\end{tabular}

Remark: Values are shown as mean \pm standard deviation. ${ }^{*}$ indicates significant differences between cold and hot season at the 0.05 level 
The t-test results showed that only the $\mathrm{TN}$ at Khon Kaen was significantly $(\mathrm{P}<0.05)$ different between the cold and hot seasons. The TP values in most provinces (Chanthaburi, Chiang Mai, Bangkok and Pathum Thani) were significantly different between the cold and hot seasons $(\mathrm{P}<0.05)$. Similarly, the chlorophyll a values in most provinces were significantly $(\mathrm{P}<0.05)$ different between the cold and hot seasons (Khon Kaen, Chanthaburi, Bangkok and Pathum Thani). Furthermore, the limiting factor was calculated as shown in Table 4. Most ponds were nitrogen limited in both the cold and hot seasons (except Khon Kaen).

Table 4. TN/TP ratio for sampled urban ponds

\begin{tabular}{ccc}
\hline \multirow{2}{*}{ Province } & \multicolumn{2}{c}{ TN/TP ratio } \\
\cline { 2 - 3 } & Cold season & Hot season \\
\hline Khon Kaen & $131.30(\mathrm{P})$ & $35(\mathrm{P})$ \\
Chanthaburi & $32.39(\mathrm{P})$ & $0.11(\mathrm{~N})$ \\
Chiang Mai & $3.68(\mathrm{~N})$ & $0.25(\mathrm{~N})$ \\
Bangkok & $2.04(\mathrm{~N})$ & $0.05(\mathrm{~N})$ \\
Pathum Thani & $3.29(\mathrm{~N})$ & $0.25(\mathrm{~N})$ \\
\hline
\end{tabular}

Remark: $(\mathrm{P})=\mathrm{P}$ is limiting; $(\mathrm{N})=\mathrm{N}$ is limiting

The phytoplankton results revealed that the Cyanophyceae were the main group of phytoplankton in all urban ponds in both cold and hot seasons. The Cyanophyceae tended to increase from the cold season to the hot season (Fig. 2). In the cold season, the dominant Division was the Cyanophyta (97\% in Chiangmai, $81 \%$ in Khon Kaen and Pathum Thani and 54\% in Chanthaburi). Pseudanabaena sp. was the dominant species in Khon Kaen with a density of 145,800 cells/L. In Chanthaburi province, Oscillatoria sp. was the dominant species with a density of 22,230 cells/L. Microcystis aeruginosa was the main species in Chiang Mai and Pathum Thani provinces with densities of 4,596,673 and 416,295 cells/L, respectively. In Bangkok the most common group was in the Division Bacillariophyceae (62\%), with Cyclotella sp. being the most dominant species at a density of $1,668,969$ cells/L.

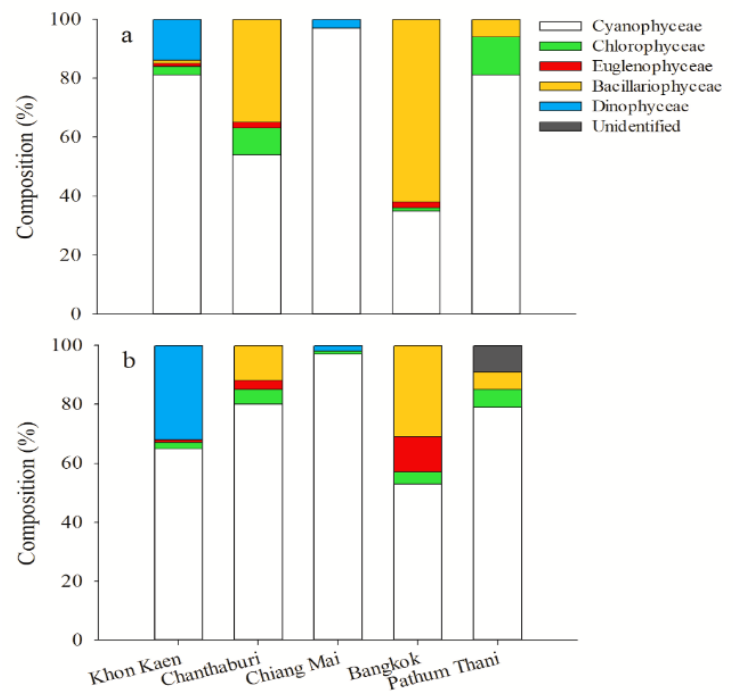

Figure 2. Phytoplankton community succession in five urban ponds (a is cold season and $b$ is hot season) 
In the hot season, the Division Cyanophyta comprised 97\% of the community in Chiang Mai, 80\% in Chanthaburi, 79\% in Prathum Thani, 65\% in Khon Kaen and 53\% in Bangkok.Cylindrospermopsis raciborskii was the dominant species (density of 283,279 cells/L in Chiang Mai, 158,265 cells/L in Chanthaburi, 467,134 cells/L in Khon Kaen and 780,612 cells/L in Pathum Thani). In Bangkok, Merismopedia minima was the dominant species with a density of 206,107 cells/L. Details of the phytoplankton present in each province are given in Table 5. Statistical analysis found no significant $(\mathrm{P}>0.05)$ differences in the phytoplankton between the cold and hot seasons for all provinces.

Table 5. Phytoplankton occurrence in each urban pond and season

\begin{tabular}{|c|c|c|c|c|c|c|c|c|c|c|}
\hline \multirow{2}{*}{ Phytoplankton } & \multicolumn{2}{|c|}{ Khon Kaen } & \multicolumn{2}{|c|}{ Chanthaburi } & \multicolumn{2}{|c|}{ Chiang Mai } & \multicolumn{2}{|c|}{ Bangkok } & \multicolumn{2}{|c|}{ Pathum Thani } \\
\hline & $\mathbf{C}$ & $\mathbf{H}$ & $\mathbf{C}$ & $\mathbf{H}$ & $\mathbf{C}$ & $\mathbf{H}$ & $\mathbf{C}$ & $\mathbf{H}$ & $\mathbf{C}$ & $\mathbf{H}$ \\
\hline Anabaena sp. & + & + & + & & & & + & + & + & ++ \\
\hline Anacystis sp. & & & + & & & & & & & \\
\hline Chroococcus sp. & & & & & & & & & & ++ \\
\hline $\begin{array}{l}\text { Cylindrospermopsis } \\
\text { raciborskii }\end{array}$ & ++ & +++ & ++ & +++ & +++ & +++ & & & & +++ \\
\hline Planktothrix sp. & & & & & & & & & & + \\
\hline $\begin{array}{c}\text { Planktolyngbya } \\
\text { limnetica }\end{array}$ & & & & & + & & & & & \\
\hline Pseudanabaena sp. & +++ & + & ++ & +++ & +++ & & & & + & \\
\hline Oscillatoria limosa & & & & & & & ++ & & & \\
\hline Osicllatoria sp. & ++ & ++ & ++ & + & +++ & & +++ & ++ & ++ & + \\
\hline Spirulina platensis & + & ++ & ++ & & & & +++ & +++ & +++ & \\
\hline Spirulina sp. & & & & + & +++ & ++ & & & & \\
\hline $\begin{array}{l}\text { Microcystis } \\
\text { aeruginosa }\end{array}$ & +++ & ++ & & & +++ & +++ & & & +++ & ++ \\
\hline $\begin{array}{l}\text { Merismopedia } \\
\text { convoluta }\end{array}$ & & & & + & & & & & & \\
\hline $\begin{array}{l}\text { Merismopedia } \\
\text { minima }\end{array}$ & + & + & + & + & & & & +++ & + & \\
\hline $\begin{array}{c}\text { Merismopedia } \\
\text { punctata }\end{array}$ & & + & & & +++ & & & & & \\
\hline Merismopedia sp. & & & & & & & & + & & \\
\hline
\end{tabular}

Remark: $\mathrm{C}=$ cold season, $\mathrm{H}=$ hot season, $+<5,000$ cells $/ \mathrm{L},++=5,001-50,000$ cells $/ \mathrm{L},+++>50,000$ cells/L

The results of the cluster analysis revealed some unique features and some similarities regarding the phytoplankton in each pond. Similarities in the phytoplankton in each pond were observed between the cold and hot seasons (Fig. 3). Furthermore, multidimensional scaling and cluster analysis showed more distinct differences in the phytoplankton at Chiang Mai, Pathum Thani and Bangkok in the hot season (approximately 60\% similarities) than in the cold season (approximately 40\% similarities). In contrast, the phytoplankton at Khon Kaen and Chanthaburi were rather similar in both the cold and hot seasons compared with the other provinces (Fig. 4). The stress value of the non-metric MDS indicated a fair (stress value 0.12 for cold season) and good (stress value 0.07 for hot season) goodness-of-fit. 

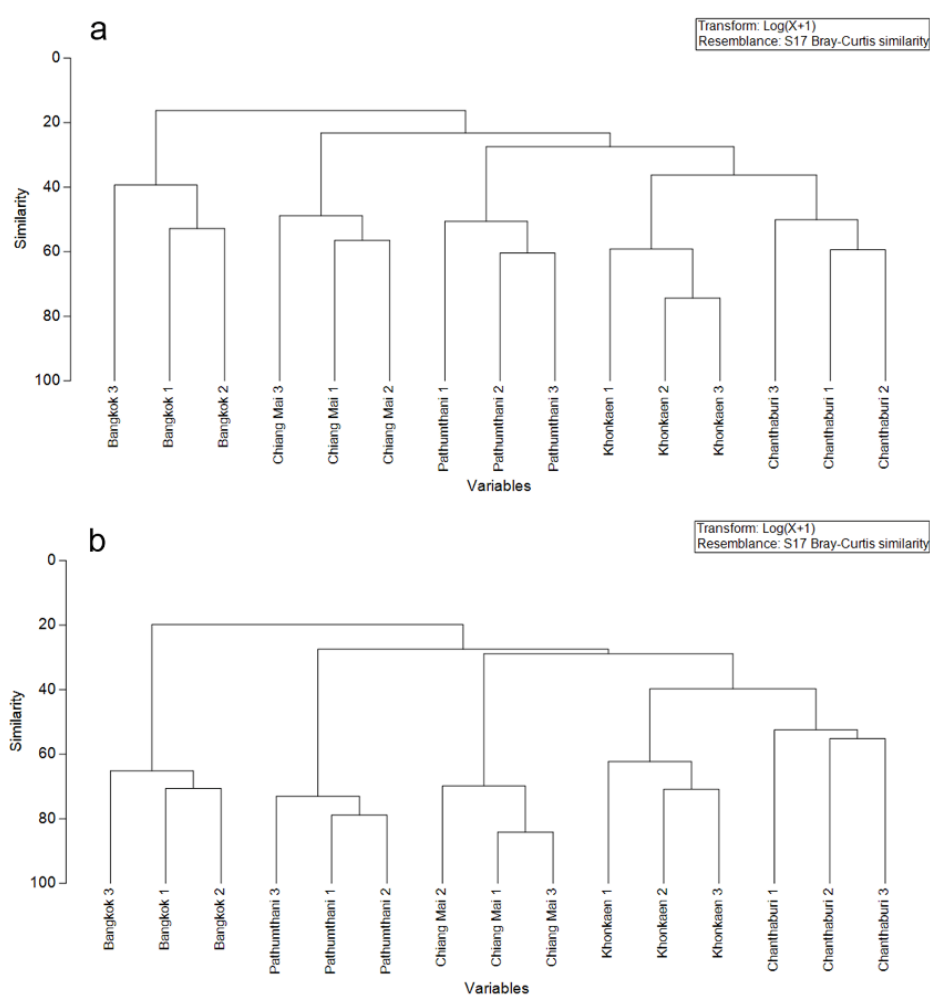

Figure 3. Cluster analysis of phytoplankton (a is cold season and $b$ is hot season). Variables represents sampling stations one, two, three of each pond (e.g. Bangkok one, two, three)
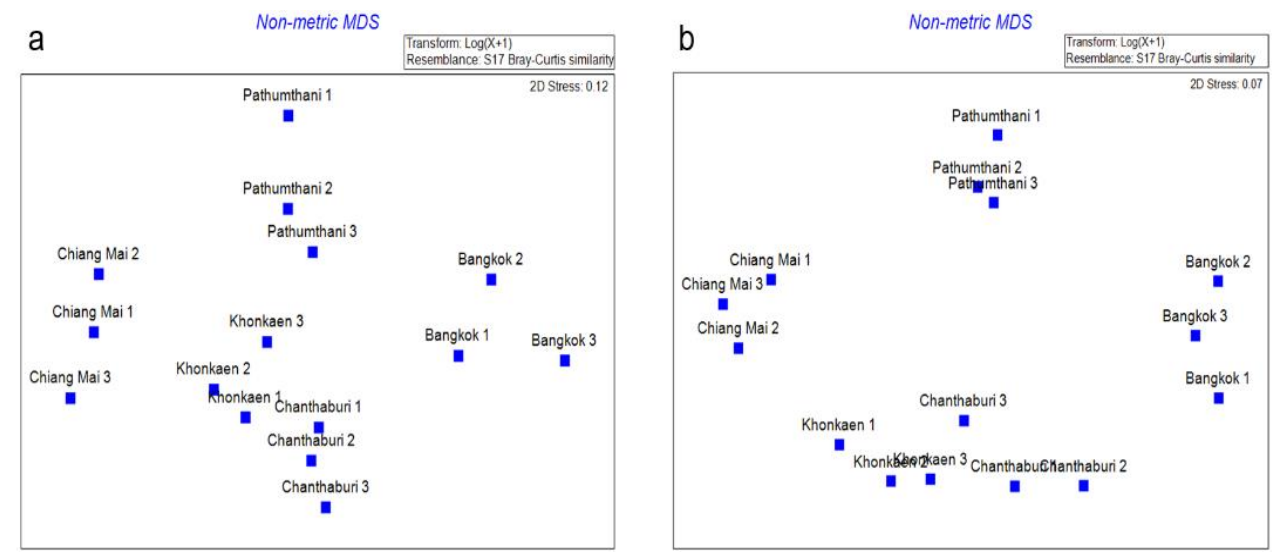

Figure 4. Multidimensional Scaling of phytoplankton ( $a$ is cold season and $b$ is hot season)

The concentration of microcystin varied among seasons and ponds (Table 6). In the cold season, the highest microcystin content was detected at Pathum Thani $(3.62 \mu \mathrm{g} / \mathrm{L})$, followed by Chanthaburi $(1.05 \mu \mathrm{g} / \mathrm{L})$, Chiang Mai $(0.52 \mu \mathrm{g} / \mathrm{L})$ and Khon Kaen $(0.063 \mu \mathrm{g} / \mathrm{L})$ provinces, respectively. In the hot season, the highest microcystin content was found in Pathum Thani $(3.10 \mu \mathrm{g} / \mathrm{L})$, followed by Khon Kaen $(0.39 \mu \mathrm{g} / \mathrm{L})$, Chanthaburi $(0.23 \mu \mathrm{g} / \mathrm{L})$ and Chiang Mai $(0.01 \mu \mathrm{g} / \mathrm{L})$ provinces, respectively. In Bangkok, no microcystin content was detected. 
Table 6. Microcystin detected in urban ponds

\begin{tabular}{ccc}
\hline Province & Season & Microcystin $(\boldsymbol{\mu g} / \mathbf{L})$ \\
\hline Khon Kaen & $\mathrm{C}$ & $0.06 \pm 0.11$ \\
& $\mathrm{H}$ & $0.39 \pm 0.41$ \\
Chanthaburi & $\mathrm{C}$ & $1.05 \pm 0.99$ \\
& $\mathrm{H}$ & $0.23 \pm 0.38$ \\
Chiang Mai & $\mathrm{C}$ & $0.52 \pm 0.90$ \\
& $\mathrm{H}$ & $0.01 \pm 0.02$ \\
Bangkok & $\mathrm{C}$ & $\mathrm{ND}$ \\
& $\mathrm{H}$ & $\mathrm{ND}$ \\
Pathum Thani & $\mathrm{C}$ & $3.62 \pm 0.43$ \\
& $\mathrm{H}$ & $3.10 \pm 0.97$ \\
\hline
\end{tabular}

Remark: MD = non detectable

\section{Discussion}

This study investigated the water quality, phytoplankton and microcystin levels in urban ponds in different regions of Thailand. The selected ponds are valuable and play crucial roles in ecosystem and human uses. However, urban ponds are in a critical condition due to exposure to nutrient pollution coming from different anthropogenic activities (e.g. wastewater from houses and restaurants) (Mayer et al., 1996). The ponds in Bangkok, Phathum Thani and Khon Kaen are functional as stormwater ponds. They are used to store runoff flow in order to mitigate flood risk during heavy rain. The ponds in Khon Kaen and Chanthaburi serve as recreational ponds, with both ponds attracting visitors coming for recreational activities such as fish feeding. Artificial feeding by the public can have adverse effects on water quality due to leftover fish feed and excretion from animals (Chaichana et al., 2011). The pond at Chanthaburi receives treated wastewater from a municipal wastewater treatment plant.

Water samples were comparatively determined between the cold season and the hot season. Water temperatures were lower in the cold season than in hot season in most ponds. The $\mathrm{pH}$ values were rather basic. The dissolved oxygen contents were in normal ranges and tended to be higher in ponds in Bangkok and Pathum Thani provinces, most likely due to photosynthesis. The turbidity and TSS were relatively high in the ponds in Bangkok, Chiang Mai and Pathum Thani and as a result there was lower transparency. Most ponds had high conductivity and TDS which could be due to contamination by pollutants from surrounding areas.

The Florida trophic state index suggested that all ponds were in a hypereutrophic condition (poor quality) in both the cold and hot seasons (Huber et al., 1982). The total phosphorus concentration peaked at $34.80 \pm 4.42 \mathrm{mg} / \mathrm{L}$, which was much higher than in other urban ponds. In the Netherlands, ponds in urban areas were highly eutrophic with mean total phosphorus concentrations between 0.16 and $0.44 \mathrm{mg} / \mathrm{L}$ (Waajen et al., 2014). In Malaysia, most lake water was in a eutrophic-hypereutrophic state (Sinang et al., 2015) with total phosphorus ranging from 15 to $4,270 \mu \mathrm{g} / \mathrm{L}$. It was also found that nitrogen $(\mathrm{N})$ rather than phosphorus $(\mathrm{P})$ appeared to be limiting factor in most ponds (except in Khon Kean). This could be explained by ponds in urban landscapes receiving $\mathrm{P}$ from washing wastewater and other anthropogenic P inputs (Mischler et al., 2014). This was in contrast with the rural ponds in agricultural landscapes where $\mathrm{N}$ appeared to be more abundant than $\mathrm{P}$, and $\mathrm{N}$ was the major cause of nutrient enrichment (Chaichana et al., 2011). 
The Cyanophyta was the main composition in all hypereutrophic urban ponds in Thailand. Phytoplankton in the Division Cyanophyta tended to increase toward the hot season in response to higher temperatures and sufficient sunlight that promoted the formation of phytoplankton (Chaichana and Dampin, 2016). This was in accordance with Jahan et al. (2010) stating that cyanobacterial blooms were positively correlated with temperature and $\mathrm{pH}$. This study also revealed that Osicllatoria, Pseudanabaena, Spirulina platensis, Microcystis aeruginosa and Merismopedia minima were common in most urban ponds. Several studies reported Cyanobaterial species such as Microcystis and Planktothrix as being dominant in eutrophic ponds (Jahan et al., 2010; Waajen et al., 2014; Sinang et al., 2015). This study found blooming phytoplankton on the water surface. In most ponds, blooms appeared only in certain areas of the water surface, depending on the influence of waves and winds. In contrast, in Pathum Thani province, intense blooms of phytoplankton occurred across the pond indicating severe eutrophication.

The current study detected microcystin in most ponds (with a peak at $3.62 \pm 0.43 \mu \mathrm{g} / \mathrm{L}$ ) except for the urban pond in Bangkok. Microcystin in this study was lower than in other studies (Waajen et al., 2014) and this may have been due to differences in the pond size and volume, residence time, water chemistry and climatic conditions (Olding et al., 2011; WHO, 2011). WHO (2011) has guidelines on cyanotoxins in drinking water with a value of $1 \mu \mathrm{g} / \mathrm{L}$ for microcystin-LR. Although the urban ponds in the current study do not provide raw water for drinking, high cyanotoxin levels could have an effect on wildlife. The highest microcystin content was in Pathum Thani and this correlated with intense blooms of Cyanobacteria, mainly $M$. aeruginosa ( $\mathrm{r}=0.407, \mathrm{P}<0.05)$. Other toxic-producing species such as Oscillatoria and Pseudanabaena (Marsalek et al., 2003; Teneva et al., 2009; Paerl and Otten, 2013) were also present. Toxic content was found in the urban pond in Chanthaburi even with the absence of $M$. Aeruginosa.

We observed some management actions taken by local government to solve eutrophication problems. For example, in Khon Kean, local officers are working on treatment of a nearby eutrophic pond using aluminum sulphate (phosphorus precipitation). The result (personal communication) was satisfactory and this treatment may be used to improve water quality of the Khon Kean pond. In Chiang Mai, some restaurants located inside the pond were removed to reduce external nutrient input. In Bangkok, as the ponds serve as water storage to deal with heavy rain in Bangkok, the water retention time is short. This reduces the formation of phytoplankton. In Chanthaburi, artificial feeding of fish in the pond should be stopped through a public educational campaign. The pond in Pathum Thani is still of concern since no restoration action has been taken so far. Therefore, recommendations for future research should focus on finding appropriate restoration methods (such as application of alum or phoslock, sediment removal, or biomanipulation) to improve water quality of these urban ponds.

In conclusion, this study determined eutrophication problems in some urban ponds of Thailand in a comparison between the cold and hot seasons. The results showed that the nutrient pollution levels were relatively high with intense eutrophication in all urban ponds in both the cold and hot seasons. Environmental conditions in the hot season appeared to stimulate phytoplankton growth. Most ponds were dominated by Cyanobacteria that produce toxins ( $M$. aeruginosa, Oscillatoria and Pseudanabaena). Microcystin contents were detected with the level depending on the degree of intensity of the bloom. These findings indicated potential health risks in water use due to the presence of microcystin. Urgent management and restoration of hypereutrophic urban ponds in Thailand is needed. 
Acknowledgements. This research was supported by the Graduate Program Scholarship from The Graduate School, Kasetsart University and partially supported by Research Group: Natural Environment in Forest and Freshwater Ecosystems, Faculty of Environment, Kasetsart University.

\section{REFERENCES}

[1] Aroonvilairat, S., Ruangyuttikarn, W., Pekkoh, J., Peerapornpisal, Y., Shen, X., Wickramasinghe, W., Shaw, G. (2004): Identification and hepatotoxicity of microcystinLR isolated from Microcystis aeruginosa Kütz. in Huay Yuak reservoir, Chiang Mai province. - Chiang Mai University Journal of Natural Sciences 7: 149-162.

[2] Bartram, J., Chorus, I. (1999): Toxic cyanobacteria in water: a guide to their public health consequences, monitoring and management. - CRC Press, London.

[3] Chaichana, R., Dampin, N. (2016): Unialgal blooms of cyanobacteria in oxidation ponds of the King's Royally Initiated Laem Phak Bia environmental research and development project, Thailand. - EnvironmentAsia 9(2): 150-157.

[4] Chaichana, R., Leah, R., Moss, B. (2011): Conservation of pond systems: a case study of intractability, Brown Moss, UK. - Hydrobiologia 664: 17-33.

[5] Ghermandi, A., Fichtman, E. (2015): Cultural ecosystem services of multifunctional constructed treatment wetlands and waste stabilization ponds: Time to enter the mainstream? - Ecological Engineering 84: 615-623.

[6] Hamer, A. J., Smith, P. J., McDonnell, M. J. (2012): The importance of habitat design and aquatic connectivity in amphibian use of urban stormwater retention ponds. - Urban Ecosystems 15: 451-471.

[7] Hassall, C. (2014): The ecology and biodiversity of urban ponds. - Wiley Interdisciplinary Reviews: Water 1: 187-206.

[8] Hill, M. J., Biggs, J., Thornhill, I., Briers, R. A., Gledhill, D. G., White, J. C., Wood, P. J., Hassall, C. (2017): Urban ponds as an aquatic biodiversity resource in modified landscapes. - Global change biology 23: 986-999.

[9] Huber, W. C., Brezonik, P. L., Heany, J. P., Dickinson, R. E., Preston, S. D., Dwornik, D. S., DeMaio, M. A. (1982): A classification of Florida lakes. - Final report to the Florida Department of Environmental Regulation. PROTECTION, F. D. O. E., Florida.

[10] Jahan, R., Khan, S., Haque, M. M., Choi, J. K. (2010): Study of harmful algal blooms in a eutrophic pond, Bangladesh. - Environmental monitoring and assessment 170: 7-21.

[11] Lakewatch, F. (2000): A beginner's guide to water management-nutrients. - Department of Fisheries and Aquatic Sciences, Institute of Food and Agricultural Sciences, University of Florida, Florida.

[12] Marsalek, B., Blaha, L., Babica, P. (2003): Analyses of microcystins in the biomass of Pseudanabaena linmnetica collected in Znojmo reservoir. - Czech Phycology 3: 195-197.

[13] Mayer, T., Marsalek, J., Reyes, E. D. (1996): Nutrients and metal contaminants status of urban stormwater ponds. - Lake and Reservoir Management 12: 348-363.

[14] Mischler, J. A., Taylor, P. G., Townsend, A. R. (2014): Nitrogen limitation of pond ecosystems on the plains of eastern Colorado. - PLoS One 9: e95757.

[15] Oertli, B., Parris, K. M. (2019): Toward management of urban ponds for freshwater biodiversity. - Ecosphere 10: 1-33.

[16] Oshima, A., Shinya, M., Kitano, M., Hagiwara, T., Goto, K., Tsuchinaga, T. (2008): Eutrophication characteristics and their relationships to chlorophyll-a concentrations in urban park ponds. - Mizu Kankyo Gakkaishi Journal of Japan Society on Water Environment 31: 701-706.

[17] Paerl, H. W., Otten, T. G. (2013): Harmful cyanobacterial blooms: causes, consequences, and controls. - Microbial Ecology 65: 995-1010. 
[18] Peretyatko, A., Teissier, S., Backer, S. D., Triest, L. (2010): Assessment of the risk of cyanobacterial bloom occurrence in urban ponds: probabilistic approach. - Annales de Limnologie - International Journal of Limnology 46: 121-133.

[19] Seekhao, I., Peerapornpisal, Y., Chantara, S. (2007): Intra-and extracellular microcystins concentrations in Mae Kuang Udomtara reservoir, Chiang Mai, Thailand in 2004-2005. J. Sci. Fac. Chiang Mai Uni. 34: 309-318.

[20] Sinang, S. C., Poh, K. B., Shamsudin, S., Sinden, A. (2015): Preliminary assessment of cyanobacteria diversity and toxic potential in ten freshwater lakes in Selangor, Malaysia. Bulletin of Environmental Contamination and Toxicology 95: 542-547.

[21] Sivonen, K. (2009): Cyanobacterial toxins. Encyclopedia of microbiology. - Elsevier Scientific Publ. Co, Amsterdam.

[22] Somdee, T., Kaewsan, T., Somdee, A. (2013): Monitoring toxic cyanobacteria and cyanotoxins (microcystins and cylindrospermopsins) in four recreational reservoirs (Khon Kaen, Thailand). - Environmental Monitoring and Assessment 185: 9521-9529.

[23] Strickland, J. D. H., Parsons, T. R. (1972): A practical handbook of seawater analysis. Fisheries research board of Canada, Ottawa.

[24] Sun, Z., Sokolova, E., Brittain, J. E., Saltveit, S. J., Rauch, S., Meland, S. (2019): Impact of environmental factors on aquatic biodiversity in roadside stormwater ponds. - Scientific Reports 9: 1-13.

[25] Teneva, I., Mladenov, R., Dzhambazov, B. (2009): Toxic effects of extracts from Pseudanabaena galeata (Cyanoprokaryota) in mice and cell cultures in vitro. - Nat. Sci. Hum 12: 237-243.

[26] Tilahun, S., Kifle, D., Zewde, T. W., Johansen, J. A., Demissie, T. B., Hansen, J. H. (2019): Temporal dynamics of intra-and extra-cellular microcystins concentrations in Koka reservoir (Ethiopia): Implications for public health risk. - Toxicon. 168: 83-92.

[27] Tixier, G., Lafont, M., Grapentine, L., Rochfort, Q., Marsalek, J. (2011): Ecological risk assessment of urban stormwater ponds: literature review and proposal of a new conceptual approach providing ecological quality goals and the associated bioassessment tools. Ecological Indicators 11: 1497-1506.

[28] Waajen, G. W. A. M., Faassen, E. J., Lürling, M. (2014): Eutrophic urban ponds suffer from cyanobacterial blooms: Dutch examples. - Environmental Science and Pollution Research 21: 9983-9994.

[29] Waajen, G., van Oosterhout, F., Douglas, G., Lürling, M. (2016): Geo-engineering experiments in two urban ponds to control eutrophication. - Water Research 97: 69-82.

[30] Whangchai, N., Wanno, S., Gutierrez, R., Kannika, K., Promna, R., Iwami, N., Itayama, T. (2013): Accumulation of microcystins in water and economic fish in Phayao lake, and fish ponds along the Ing river tributary in Chiang Rai, Thailand. - Agricultural Sciences 4: 52.

[31] WHO (2011): Guidelines for drinking-water quality. - IWA Publishing, London.

[32] Zamora-Barrios, C. A., Nandini, S., Sarma, S. S. S. (2019): Bioaccumulation of microcystins in seston, zooplankton and fish: A case study in Lake Zumpango, Mexico. Environmental Pollution 249: 267-276. 